\title{
1 Absence of SARS-CoV-2 antibodies in pre-pandemic plasma from 2 children and adults in Vietnam
}

3 Nguyen Van Vinh Chau ${ }^{1}$, Le Nguyen Thanh Nhan $^{2}$, Lam Anh Nguyet ${ }^{3}$, Nguyen Thi Kha $4 \mathrm{Tu}^{4}$, Nguyen Thi Thu Hong ${ }^{3}$, Dinh Nguyen Huy Man ${ }^{1}$, Dinh Thi Bich Ty ${ }^{1}$, Le Nguyen 5 Truc $\mathrm{Nhu}^{3}$, Lam Minh Yen ${ }^{3}$, Truong Huu Khanh', Ngo Ngoc Quang Minh', Nguyen Thi $6 \mathrm{Han} \mathrm{Ny}^{3}$, Danielle Anderson ${ }^{5}$, Lin-Fa Wang ${ }^{5,6}$, H. Rogier van Doorn ${ }^{3,7}$, Nguyen Thanh 7 Hung ${ }^{2}$, Tran Tan Thanh ${ }^{3}$, Guy Thwaites ${ }^{3,7}$ and Le Van Tan $^{3}$ for OUCRU COVID-19 8 research group*

$9 *$ Members of the Group are listed in the acknowledgements

$10 \quad{ }^{1}$ Hospital for Tropical Diseases, Ho Chi Minh City, Vietnam

$11{ }^{2}$ Children's Hospital 1, Ho Chi Minh City, Vietnam

$12{ }^{3}$ Oxford University Clinical Research Unit, Ho Chi Minh City, Vietnam

$13{ }^{4}$ Dong Thap Provincial Center for Disease Control, Dong Thap Province, Vietnam

$14{ }^{5}$ Duke-NUS Medical School, Singapore

$15 \quad{ }^{6}$ SingHealth Duke-NUS Global Health Institute, Singapore

$16{ }^{7}$ Centre for Tropical Medicine and Global Health, Nuffield Department of Medicine, 17 University of Oxford, Oxford, UK

18 Correspondence: Le Van Tan, email: tanlv@oucru.org

19 Abstract: 48 words

20 Main text: 791 words

21 Running title: SARS-CoV-2 antibodies in pre-pandemic plasma

22 Key words: Cross-reactivity, SARS-CoV-2, zoonosis, COVID-19 
23 Abstract: We tested pre-pandemic (2015-2019) plasma samples from 148 Vietnamese

24 children, and 100 Vietnamese adults at high risk of zoonotic infections, for antibodies

25 against SARS-CoV-2 nucleocapsid and spike proteins. None was positive, indicating no

26 prior serological cross-reactivity with SARS-CoV-2 that might explain the low numbers of

27 COVID-19 in Vietnam. 
medRxiv preprint doi: https://doi.org/10.1101/2021.07.12.21260379; this version posted July 15, 2021. The copyright holder for this preprint

\section{Main text}

29 Severe acute respiratory syndrome coronavirus 2 (SARS-CoV-2) emerged in late 2019,

30 and is the cause of the ongoing coronavirus disease 2019 (COVID-19) pandemic. Yet,

31 according to the World Health Organization, countries in the Western Pacific region,

32 including Vietnam, have so far reported only a small fraction of the global COVID-19

33 cases. One hypothesis is that there may be pre-existing immunity among the population in

34 the region through exposure to SARS-CoV-2 related viruses. Knowledge of this might help

35 explain why the burden posed by SARS-CoV-2 and the incidence of COVID-19 cases vary

36 significantly across the world. It may also further shed light on the natural course of the

37 infection.

38 A total of 148 young Vietnamese children with hand, foot and mouth disease [1], and 100

39 Vietnamese adults were included for analysis of antibodies responses against SARS-CoV-

40 2. The latter was those in close contact with domestic and/or wild animals and was thus at

41 high risk for zoonotic infections as detailed elsewhere [2]. Of the 148 children, 8 children

42 had RT-PCR confirmed evidence of current infection with either human coronavirus NL63

43 (HCoV-NL63) $(\mathrm{n}=2)$ or human coronavirus OC43 $(\mathrm{HCoV}-\mathrm{OC} 43)(\mathrm{n}=6)$, and one adult had

44 HCoV-OC43 detected in an earlier sample by RT-PCR. For the 100 adult cohort

45 participants, we used plasma samples collected at baseline and two years later [2]. For

46 children, we used 148 admission plasma from each participant, and two available

47 convalescent plasma samples from $2 / 8$ human coronavirus positive individuals. We

48 included 350 plasma samples in total for the analysis. We extracted information about

49 demographics, occupation and animal contact from the metadata of the aforementioned

50 original studies. 
medRxiv preprint doi: https://doi.org/10.1101/2021.07.12.21260379; this version posted July 15, 2021. The copyright holder for this preprint

51 We measured antibodies against two main immunogens (the nucleocapsid $(\mathrm{N})$ and spike

52 (S) proteins) of SARS-CoV-2 using two well-validated sensitive and specific serological

53 assays, namely Elecsys Anti-SARS-CoV-2 assay (Roche, Germany) [3] and SARS-CoV-2

54 Surrogate Virus Neutralization Test (sVNT) (GenScript, USA) [4]. The former is an

55 electrochemiluminescence immunoassay using recombinant $\mathrm{N}$ protein for qualitative

56 detection of pan immunoglobulin (Ig) (including $\mathrm{IgG}$ ) against SARS-CoV-2. The latter is a

57 surrogate assay for measuring spike protein receptor binding domain (RBD)-targeting

58 neutralizing antibodies (RBD-targeting NAbs) [4]. These two assays detected SARS-CoV-

592 antibodies in plasma samples from 11/11 Vietnamese patients with PCR-confirmed

60 SARS-CoV-2 infection collected $2-3$ weeks after diagnosis (data not shown). The

61 institutional review board of collaborating hospitals in Vietnam and the Oxford Tropical

62 Research Ethic Committee approved the clinical study.

63 The 248 study participants came from various geographic locations in Southern Vietnam

64 (Table 1 and Figure 1). They were all enrolled in the clinical studies between March 2013

65 and July 2019 (before the COVID-19 pandemic). Of the adult participants, farmers were

66 predominant $(n=42)$, followed by animal slaughterers $(n=32)$ and animal health workers

67 ( $\mathrm{n}=26)$. The 148 children all had hand foot and mouth disease, and included 89 females

68 and 59 males; the median age was 18 months.

69 None of the 350 plasma samples tested had detectable antibodies against N protein SARS-

70 CoV-2. Additionally, RBD-targeting NAbs were not detected in 240 available plasma

71 samples from the 100 adults and 38 children (including 10 from 8 positive for $\mathrm{HCoV}$ -

72 NL63 or HCoV-OC43). 
medRxiv preprint doi: https://doi.org/10.1101/2021.07.12.21260379; this version posted July 15, 2021. The copyright holder for this preprint

73 Using in-house immunofluorescence assays, a recent study demonstrated that antibodies

74 against spike or nucleocapsid proteins were detected in $19 \%(\mathrm{n}=105)$ and $14.1 \%(\mathrm{n}=99)$

75 pre-pandemic plasma samples collected in Tanzania and Zambia, respectively [5]. Cross

76 reactivity was strongly correlated with the presence of pre-existing antibodies against

77 HCoV-NL63. Most recently, SARS-CoV-2 cross reactive antibodies, especially

78 neutralizing antibodies, were also detected in pre-pandemic plasma from SARS-CoV-2 un-

79 infected individuals in the UK [6].

80 Human coronaviruses cause the common cold worldwide with sero-prevalence increasing

81 with age [7]. Thus, it is likely that in addition to the 9 individuals of the present study with

82 evidence of human coronavirus infection by reverse transcription polymerase chain

83 reaction, a proportion of the study participants were also exposed to these coronaviruses

84 some time in the past. Therefore, previous exposure to known human coronaviruses alone

85 might not determine the observed cross reactivity in pre-pandemic plasma. Other possible

86 contributing factors include the difference in assay performance and/or the heterogeneities

87 between the study populations, which merits further research.

88 Both cellular and humoral immunities are two major components of host responses. The

89 former was not explored in the present study due to the unavailability of peripheral blood

90 mononuclear cells. Of note, SARS-CoV-2-reactive T cells were detected in 20 to $50 \%$ of

91 blood collected from unexposed individuals from various geographic locations (Germany,

92 Singapore, the Netherlands, the United States and the United Kingdom) [8-10]. The

93 correlation with protection of these pre-existing immunities remains unknown.

94 In summary, antibodies against SARS-CoV-2 nucleocapsid and spike proteins were not

95 detected in 350 pre-pandemic Vietnamese plasma samples. Future studies should look at 
medRxiv preprint doi: https://doi.org/10.1101/2021.07.12.21260379; this version posted July 15, 2021. The copyright holder for this preprint (which was not certified by peer review) is the author/funder, who has granted medRxiv a license to display the preprint in perpetuity.

It is made available under a CC-BY 4.0 International license .

96 pre-existing B cell and T cell memory in pre-pandemic samples, which might further shed

97 light on the pathogenesis of the infection. 
medRxiv preprint doi: https://doi.org/10.1101/2021.07.12.21260379; this version posted July 15, 2021. The copyright holder for this preprint

(which was not certified by peer review) is the author/funder, who has granted medRxiv a license to display the preprint in perpetuity.

It is made available under a CC-BY 4.0 International license.

\section{Acknowledgements}

This study was funded by the Wellcome Trust of Great Britain (106680/B/14/Z and 204904/Z/16/Z). The serology work at Duke-NUS is supported by grants from NMRC, Singapore (STPRG-FY19-001 and COVID19RF-003). We thank members of the VIZIONS consortium and staff from the Departments of Health

104

105 and Preventative Medicine Centers (PMC) of Dak Lak and Dong Thap provinces for provision of samples, and thank VIZIONS cohort members in Dak Lak and Dong Thap provinces for their participation in the study. We are indebted to Ms Le Kim Thanh and Ms Pham Thi Hong Anh for their logistic support. We thank the patients for their participations in this study. We would also like to thank Mr Dinh Khac Hieu for his laboratory support with the ELISA analysis.

\section{OUCRU COVID-19 Research Group}

110 Hospital for Tropical Diseases, Ho Chi Minh City, Vietnam: Nguyen Van Vinh Chau, 111 Nguyen Thanh Dung, Le Manh Hung, Huynh Thi Loan, Nguyen Thanh Truong, Nguyen 112 Thanh Phong, Dinh Nguyen Huy Man, Nguyen Van Hao, Duong Bich Thuy, Nghiem My 113 Ngoc, Nguyen Phu Huong Lan, Pham Thi Ngoc Thoa, Tran Nguyen Phuong Thao, Tran 114 Thi Lan Phuong, Le Thi Tam Uyen, Tran Thi Thanh Tam, Bui Thi Ton That, Huynh Kim 115 Nhung, Ngo Tan Tai, Tran Nguyen Hoang Tu, Vo Trong Vuong, Dinh Thi Bich Ty, Le 116 Thi Dung, Thai Lam Uyen, Nguyen Thi My Tien, Ho Thi Thu Thao, Nguyen Ngoc Thao,

117 Huynh Ngoc Thien Vuong, Pham Ngoc Phuong Thao, Phan Minh Phuong

118 Oxford University Clinical Research Unit, Ho Chi Minh City, Vietnam: Dong Thi Hoai Tam, Evelyne Kestelyn, Donovan Joseph, Ronald Geskus, Guy Thwaites, H. Rogier van Doorn, Ho Van Hien, Huynh Le Anh Huy, Huynh Ngan Ha, Huynh Xuan Yen, Jennifer Van Nuil, Jeremy Day, Joseph Donovan, Katrina Lawson, Lam Anh Nguyet, Lam Minh Yen, Le Nguyen Truc Nhu, Le Thanh Hoang Nhat, Le Van Tan, Sonia Lewycka Odette, Louise Thwaites, Maia Rabaa, Marc Choisy, Mary Chambers, Motiur Rahman, Ngo Thi Hoa, Nguyen Thanh Thuy Nhien, Nguyen Thi Han Ny, Nguyen Thi Kim Tuyen, Nguyen Thi Phuong Dung, Nguyen Thi Thu Hong, Nguyen Xuan Truong, Phan Nguyen Quoc Khanh, Phung Le Kim Yen, Sophie Yacoub, Thomas Kesteman, Nguyen Thuy Thuong Thuong, Tran Tan Thanh, Tran Tinh Hien, Vu Thi Ty Hang 
medRxiv preprint doi: https://doi.org/10.1101/2021.07.12.21260379; this version posted July 15, 2021. The copyright holder for this preprint (which was not certified by peer review) is the author/funder, who has granted medRxiv a license to display the preprint in perpetuity.

It is made available under a CC-BY 4.0 International license.

128

129

130

131

132

133

134

135

136

137

138

139

140

141

142

143

144

145

146

147

148

149

150

151

152

153

154

\section{References}

1. Nhan, L.N.T., et al., Clinical, etiological and epidemiological investigations of hand, foot and mouth disease in southern Vietnam during 2015 - 2018. PLoS Negl Trop Dis, 2020. 14(8): p. e0008544.

2. $\quad$ Nguyen, T.T.K., et al., Respiratory viruses in individuals with a high frequency of animal exposure in southern and highland Vietnam. J Med Virol, 2020. 92(8): p. 971-981.

3. Ainsworth, M., et al., Performance characteristics of five immunoassays for SARSCoV-2: a head-to-head benchmark comparison. The Lancet Infectious Diseases, 2020. 20(12): p. 1390-1400.

4. Tan, C.W., et al., A SARS-CoV-2 surrogate virus neutralization test based on antibody-mediated blockage of ACE2-spike protein-protein interaction. Nat Biotechnol, 2020. 38(9): p. 1073-1078.

5. Tso, F.Y., et al., High prevalence of pre-existing serological cross-reactivity against SARS-CoV-2 in sub-Sahara Africa. Int J Infect Dis, 2020.

6. $\quad \mathrm{Ng}, \mathrm{K}$.W., et al., Preexisting and de novo humoral immunity to SARS-CoV-2 in humans. Science, 2020. 370(6522): p. 1339-1343.

7. Dijkman, R., et al., Human coronavirus NL63 and $229 E$ seroconversion in children. J Clin Microbiol, 2008. 46(7): p. 2368-73.

8. Mateus, J., et al., Selective and cross-reactive SARS-CoV-2 T cell epitopes in unexposed humans. Science, 2020. 370(6512): p. 89-94.

9. Le Bert, N., et al., SARS-CoV-2-specific T cell immunity in cases of COVID-19 and SARS, and uninfected controls. Nature, 2020. 584(7821): p. 457-462.

10. Grifoni, A., et al., Targets of T Cell Responses to SARS-CoV-2 Coronavirus in Humans with COVID-19 Disease and Unexposed Individuals. Cell, 2020. 181(7): p. 1489-1501 e15. 
medRxiv preprint doi: https://doi.org/10.1101/2021.07.12.21260379; this version posted July 15, 2021. The copyright holder for this preprint (which was not certified by peer review) is the author/funder, who has granted medRxiv a license to display the preprint in perpetuity.

It is made available under a CC-BY 4.0 International license .

\section{ABOUT THE AUTHOR}

156 Dr Nguyen Van Vinh Chau is the Director of the Hospital for Tropical Diseases in Ho Chi

157 Minh City, Vietnam. He is a frontline health care worker of the COVID-19 pandemic 
medRxiv preprint doi: https://doi.org/10.1101/2021.07.12.21260379; this version posted July 15, 2021. The copyright holder for this preprint (which was not certified by peer review) is the author/funder, who has granted medRxiv a license to display the preprint in perpetuity.

It is made available under a CC-BY 4.0 International license.

Table 1: Demographics and animal contacts of the study participants

\begin{tabular}{|l|c|c|}
\hline Variables & Children, N=148 & Adults, N=100 \\
\hline Age $^{\#}$ & $18(1-153)$ & $44(21-72)$ \\
\hline Female/male & $89 / 59(1.5)$ & $32 / 68(0.47)$ \\
\hline Occupation, n (\%) & & $42(42 \%)$ \\
\hline Slaughters & NA & $32(32 \%)$ \\
\hline Animal health workers & NA & $26(26 \%)$ \\
\hline HCMC origin & $62(41.89 \%)$ & 0 \\
\hline Other provinces & $86(58.11 \%)$ & $100(100 \%)^{w}$ \\
\hline Collection period & June, 2015- July, 2019 & March, 2013- September, 2016 \\
\hline $\begin{array}{c}\text { Activity/event at risk of } \\
\text { zoonotic infection }\end{array}$ & NA & $63(63 \%)$ \\
\hline Raising domestic animals & NA & $16(16 \%)$ \\
\hline Raising wild animals & NA & $19(19 \%)$ \\
\hline Bitten by animals & NA & $42(42 \%)$ \\
\hline Bloody injuries* & & \\
\hline
\end{tabular}

Note to Table 1: ${ }^{*}$ in months, median (range) for children and in years, median (range) for adults

"50 from Dong Thap province and 50 from Dak Lak province

Domestic animals include dogs, chicken, pigs, cats, duck, muscovy duck, pigeons, cattle, geese, goat, rabbits, buffalo and turkeys.

Wild animals include wild pigs, deers, porcupines and monkeys.

Other provinces includeAn Giang (8), Ba Ria Vung Tau (2), Bac Lieu (1), Ben Tre (4), Binh Duong (4), Binh Phuoc (2), Binh Thuan (1), Ca Mau (1), Can Tho (3), Dong Nai (3), Dong Thap (2), Kien Giang (2), Lam Dong (1), Long An (15), Quang Ngai (1), Soc Trang (1), Tay Ninh (13), Tien Giang (18), Tra Vinh (3) and Vinh Long (1). The geographic locations of these provinces can be found in Figure 1.

*Bloody injuries while working with animals. 


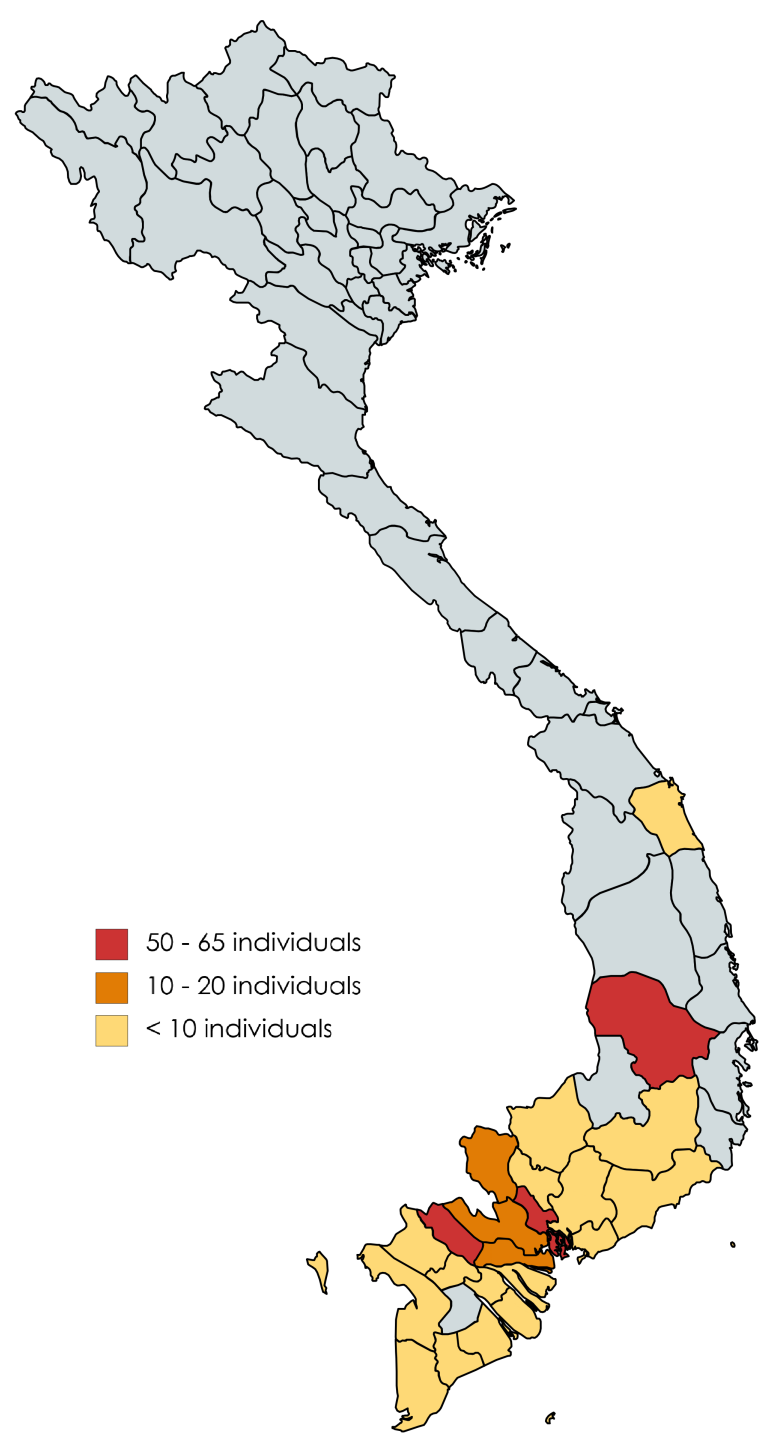

Figure 1: Map showing the geographic distributions of the study participants. (Inset map; https://mapchart.net). 